\title{
DAMAGES FOR PERSONAL INJURY: THE IMPACT OF INSURANCE
}

\author{
Lours L. JAFFE*
}

I

The law grows daily more hospitable to insurability in lieu of fault as the premise of liability for personal injury. ${ }^{1}$ The basic fact is the pervasive and systematic use of machinery. The consequence is high productivity and vast markets. These in turn have given rise to a concept of measurable risk and an ability to set aside part of the product to insure the risk. Judges no longer fear to accept this view, if not always overtly, as the major premise of the administration of the traditional concepts. But this creates certain contradictions which are only dimly felt or deliberately ignored. These seem to me to be particularly acute in the field of damages. ${ }^{2}$

In some situations the law has explicitly discarded the requirement of fault. A goodly number of courts, for example, having used MacPherson v. Buick Motor Co. ${ }^{3}$ as a bridge, hold a manufacturer liable to ultimate consumers for "breach of warranty" without a showing of fault. But even where the law still insists on the syntax of fault and speaks this language it may characterize as negligent, conduct which by the earlier legal standard or by present colloquial standards is quite innocent. In a recent FELA case ${ }^{4}$ an employee was alleged to have tripped on a clinker or piece of coal present on a railroad way. The presence of the clinker was held to be sufficient allegation of the railroad's negligence. I hazard the opinion that there are very few persons who believe that the failure to remove a stray clinker is a failure to observe the dictates of decent neighborly regard. The clinker is a point d'appui, a concrete entity around which it is possible to spin the speech of negligence. It would be a mistake, to be sure, to suppose that the older conceptions are

*A.B., Johns Hopkins University; LI.B., S.J.D., Harvard University. Member of the California and New York bars. Professor of Law, University of Buffalo, r936-r948, Dean, 1948-r950; Professor of Law, Harvard University, since $195^{\circ}$.

I The literature is large. Most of it is collected in Ehrenzweig, Negligence Withour Fault 9 et seq. (195r). See particularly James, Accident Liability Reconsidered: The Impact of Liability Instrance, 57 Yale L. J. 549 (1948); Gregory, Trespass to Negligence to Absolute Liability, 37 VA. L. REv. 359 (195I).

${ }^{2}$ Among those who stress and applaud the trend toward insurability there is practically no discussion of the damage problem. Ehrenzweig, however, who writes as much from the point of view of insurance as of tort liability, does suggest it. Op. cit. supra note $I$, at 64 . On the other hand see McNiece and Thornton, Is the Law of Negligence Obsolete?, 26 Sr. JoHns L. Rev. 255, 274 (r952), discussed below at the conclusion of this article.

${ }_{217}$ N. Y. 382 , III N. E. I050 (I916).

4Brown v. Western Ry. of Alabama, 338 U. S. 294 (1949). The case of course involves strictly only a pleading question. The plea was that defendant had allowed clinkers and other debris to collcct along the side of the track so as to make the yards unsafe and that plaintiff had slipped on a clinker. The Georgia court held this an insufficient allegation of negligence; the Supreme Court reversed. 
entirely ignored. The advance sheets teem with negligence appeals. Reversals for lack of evidence are not uncommon. Indeed recently the Supreme Court upheld the judgment of a court of appeals in an FELA case setting aside a verdict for lack of evidence. ${ }^{5}$ There appeared to be no reason whatever for that august tribunal even to hear this case on certiorari. Perhaps certiorari was taken so that the Court might make somewhat ostentatious vindication of the power of the courts of appeals to preserve the tattered remnants of the older view.

But these spasmodic reaffirmations of the traditional law of negligence meet with disapproval and even at times with almost angry protest. Mr. Justice Black appears to believe that the sufficiency of the evidence is exclusively for the jury, at least if it is possible to imagine some theory of negligence. ${ }^{6}$ His view does not reject the linguistics of negligence, but it denies the power of the judge to control the jury, a feature which is accepted for civil trials generally, and, so one would suppose, for negligence trials. I do not think that it is presumptuous to infer that for Mr. Justice Black negligence should not be a necessary predicate for recovery, at least by an employee against his employer. Of course that view is almost universally held in so far as it is embodied in an explicitly prescribed insurance scheme of workmen's compensation. But Mr. Justice Black is prepared to take a similar view of the tort action and so as it were to assert that one who is the victim of an insurable risk is justly entitled to recover.

Professor Fleming James has expressed ${ }^{7}$ much the same feeling about liability for automobile injuries in an interesting but somewhat obscure thesis built around the concept of "accident proneness." His point appears to be that since negligence is attributable to accident proneness, and accident proneness is a character trait, a patterned way of responding, the concept of negligence is emptied of any element of blame. It is thought then to follow that since blame is absent, the concept of negligence is without significance either to create liability or to defeat it (contributory negligence). Essentially, of course, this is nothing other than a new and fashionable garb for determinism. That fault has become a deeply ingrained habit does not in the slightest negative the accepted notion of fault. Whether fault is an effect of free will is a question that each decides for himself, but the law, following the common instinct, treats fault as a moral dictum and not less so because it has become habitual. There is, however, no denying that for most of us the question of the individual's moral responsibility for fault arouses deep and discomforting metaphysical distress. The modern man is thus driven to avoid where possible solutions that invoke the concept of fault.

To some degree this solution has already been achieved by the notion that the

\footnotetext{
${ }^{5}$ Moore v. Chesapeake \& O. Ry., 340 U. S. 573 (195I). (Black and Douglas, JJ., dissenting.) Other recent cases holding evidence insufficient are Jaroszewski v. Central R. R., 9 N. J. 23I, 87 A. 2d 705 (I952), cert. denied, 73 Sup. Ct. 26 (1952) (Black, J., dissenting); Chesapeake \& Ohio Ry. v. Thomas, 198 F. 2d 783 (4th Cir. 1952) (2-1); Eckenrode v. Pennsylvania R. R., 164 F. 2d 996 '(3rd Cir. 1947) (2-I), aff'd, 335 U. S. 329 (1948) (5-4).

'Note his votes in the cases cited in note 5 , supra.

${ }^{7}$ James and Dickinson, Accident Proneness and Accident Law, 63 HArv. L. Rev. 769 (1950).
} 
standard for judging the defendant's conduct is not his own but the "reasonable man's." In the majority of cases, however, the discourse concerning due care is in terms which the ordinary man would accept as his own, and were the standard seriously applied a defendant would be judged by the criteria which he more or less applies to his own affairs. But, even so, in the ordinary negligence case it is not the fault of the defendant which accounts for the law's concern; it is the injury to plaintiff. The defendant's fault (beyond the important fact of his bare connection with the plaintiff's injury) provides the law with a basis for compensating the plaintiff. It has become increasingly obvious that certain activities create foreseeable risks which society can afford to insure. If plaintiff has suffered injury of the foreseeable type, it seems that insurability is a much better reason for compensation than fault in the pallid sense in which it is now understood. And it has the superior virtue that the plaintiff recovers in every case. ${ }^{8}$

If then the judges have not entirely abandoned negligence they are under great pressure to do so from within and from without. Sensitive judges are caught in a dreadful cross-fire. The common law and statute enjoin them to talk the language of fault and to administer it in customary ways. Yet there is a pervasive atmosphere constantly suggesting that adherence to the concept is anachronistic and reactionary. This makes for continuous erosion both in doctrine and administration. It is this question of liability to which lawyers, judges, and scholars have for the most part directed their attention. But the question of damages on the other hand has had as yet very little attention. When liability rests on insurability rather than on notions of fault, there arise, as it seems to me, questions as to the rationalization of certain principles of compensation which are at present taken for granted.

\section{II}

I suggest that the crucial controversy in personal injury torts today is not in the area of liability but of damages. Questions of liability have great doctrinal fascination. Questions of damage-and particularly their magnitude-do not lend themselves so easily to discourse. Professors dismiss them airily as matters of trial administration. Judges consign them uneasily to juries with a minimum of guidance, occasionally observing loosely that there are no rules for assessing damages in personal injury cases. 9 There is analogy for this situation in Jerome Frank's complaint that fact finding, though of paramount importance, is neglected by teachers who devote themselves too exclusively to appellate law. This may reflect not so

${ }^{8}$ Clarence Morris warns us that we must not assume that an enterprise defendant is necessarily in a better position than plaintiff to insure. Hazardous Enterprises \& Risk Bearing Capacity, 6r YaLE L. J. II72 (1952). Thus, fire risk is ordinarily more effectively and more bearably insured by plaintiff. This is the reason behind two much maligned cases which have always seemed to me correctly decided. Ryan v. New York Central Ry., 35 N. Y. 210, 91 Am. Dec. 49 (I866); Moch Co. v. Rensselaer Water Co., 247 N. Y. 160, 159 N. E. 896 (1928). However, in neither of these cases do the opinions proceed frankly on this basis, and it is the rationalizations which have given offense.

${ }^{\circ}$ In Atlantic Coast Line R. R. v. Withers, I92 Va. 493, 510, 65 S. E. 2d 654, 663 (I95I), the court quoted the following from an earlier Virginia decision: "The settled rule is that, as there is no legal measure of damages in cases involving personal injuries, the verdict of the jury in such cases cannot be set aside as excessive...." 
much their judgment of relative importance (as Judge Frank supposes) as the relative adaptability of the subjects to conceptualization. And so it probably is with the subject of damages.

The size of the personal injury verdict has increased enormously in the last few years. ${ }^{10}$ A number of factors have combined to swell it. The earliest of these has been the movement for the recognition and fuller protection of the imponderable interests of personality: freedom from mental distress-pain, sorrow, anxiety, irritation - in so far as these have been the consequences of socially unjustified activity. Judicial and legislative resistance to these demands has been considerably disarmed. This has coincided with a higher standard of living, a growing sense of entitlement to "security" (both of these resting on a constant rise in productivity), and finally a persistent inflation. These factors by reaction on each other multiply the product. Our concern about "security" grows as our stake in it grows and this in turn increases sensitivity to inflation. Here is a fertile field for pressure, a hothouse for "forcing."

We have come to accept almost without question the monetary evaluation of the immeasurable perturbations of the spirit. But why should the law measure in monetary terms a loss which has no monetary dimension? If $A$ takes $B$ 's chattel he should return it or pay for it; if he destroys it he has had his way with $B$ 's goods and should pay. At least this seems clear where $A$ 's conduct is blameworthy. $A$ has or has had what is $B$ 's and if the law can return to $B$ the chattel or its equivalent it is acting on the maxim to each his own. The case provides an analogy for a case involving a total or partial destruction of $B$ 's earning power. If $A$ 's act was innocent, under the modern law he has not had to pay. Though in a sense he may be said to have taken away, he has not received anything. Where, however, he has wrongfully deprived $B$ of his earning power the law can and will order him to return its equivalent. But what of the apprehension of injury, and the pain and suffering of it? At this point the analogy to the deprivation of a valued good breaks down. This is clearly true of suffering which is in the past. It is less true for pain still to be faced. The pain I have suffered may leave me a better or a worse man, it may leave me with a memory of pain or a sense of gratitude for pain departed. To put a monetary value on the unpleasant emotional characteristics of experience is to function without any intelligible guiding premise.

When the defendant's conduct is reprehensible damages are an apt instrument of punishment. ${ }^{11}$ The criminal law is often a clumsy and ineffective device for dealing with unsocial activity. The engines of public prosecution may be too

${ }^{10}$ The Journal of the National Association of Claimants Compensation Attorneys (NACCA) publishes lists of verdicts of over $\$ 50,000$. Its list is often referred to by courts to justify large verdicts. This Association is, as the name implies, an association of "plaintiff" attorneys. There have, of course, for many years been associations of insurance attorneys and agents whose activitics and journals are devoted to the minimization of liability. The NACCA is a "countervailing" trade journal devoted to maximizing liability and, if understood to be such, serves a useful informative and argumentative function.

11 There are valuable thoughts and citations on exemplary damages in Professor Ehrenzwcig's report for the New York Law Revision Commission: Multiple Damages, Leg. Doc. (1944) No. 65 (J). 
ponderous or too busy with high crimes. The tort law serves as a useful supplement or alternative. To pay money to one's victim is a salutary humiliation. The victim is the focus of the communal sense of having been wronged. The receipt of money particularly from the wrongdoer assuages a justified sense of outrage. It is true that here the law does operate without any adequate premise for measurement or alternative. To pay money to one's victim is a salutary humiliation. The as society holds that punishment serves a useful function. It is perhaps possible to provide a measure by relating monetary punishment to the size of the defendant's income. ${ }^{12}$ Many courts arbitrarily restrict punitive damages, probably a wise expedient in an area where there is no guide to judgment. ${ }^{13}$

Rationalization becomes more obscure and wavering when the defendant's conduct is merely negligent rather than willful. It is customarily said that the purpose of a tort action is compensation rather than punishment, particularly where the gist of the action is negligence. When the plaintiff's damage is restricted to mental distress the courts have quite consistently denied any recovery but once given physical injury as a predicate, pain and suffering is allowed as "parasitic damage."14 The court will invariably admit that there is no measure for its valuation but it is thought that justice nevertheless demands its equation into money. In a recent FELA case ${ }^{15} \$ 40,000$ was allowed for pain and suffering. It might just as well have been $\$ 10,000$ or $\$ 100,000$, though a court sometimes by an intuitive judgment, sometimes by rote, will set limits. A factor of such dimensions and yet so subject

\footnotetext{
${ }^{12}$ In tort cases involving a punitive element many courts allow a showing of the defendant's wealth, though some do not. E.g., Pendleton v. Norfolk \& Western Ry., 82 W. Va. 270, 95 S. E. 94I (r918), annotated 16 A. L. R. $77 \mathrm{I}$ (I922). See discussion in Wilson v. Onondaga Radio Broadcasting Corp., I75 Misc. 389,23 N. Y. S. 2 d 654 (Sup. Ct. 1940) disapproving of evidence as to defendant's wealth.

More rarely do courts consider the defendant's poverty in reducing damages. E.g., Jackson v. Briede, I56 La. 573, 100 So. 722, 726 (I924).

Ehrenzweig, Assurance Oblige, 15 LAw \& Contemp. Pros. 445, 447 (1950), notes that some of the European codes permit the court to consider relative wealth in assessing damages in tort cases; the idea is not restricted to cases of punitive damages.

${ }^{13}$ See notes in 16 A. R. L. 76 I (r922), I23 A. L. R. Ir36 (I939), 17 A. L. R. 2d 527 (195r).

${ }^{24}$ It will be remembered that Street in a well-known passage in his The Foundations of Legal Liability (Vol. I, at 470 (I906)) said in speaking of "mental distress":

"The treatment of any element of damage as a parasitic factor belongs essentially to a transitory stage of legal evolution. A factor which is today recognized as parasitic will, forsooth, tomorrow be recognized as an independent basis of liability. It is merely a question of social, economic, and industrial needs as those needs are reflected in the organic law."

At Page 475, Street asks whether a recognition of mental distress does answer to "the needs of a complex and enlightened society." He seems to doubt it. He quotes Lurton, J., dissenting in Wadsworth v. Western Union Tel. Co., 86 Tenn. 695, 721, 8 S. W. 574, 582-583 (1888):

"Such injuries are generally more sentimental than substantial, depending largely upon physical and nervous condition. The suffering of one under precisely the same circumstances would be no test of the suffering of another. Vague and shadowy, there is no possible standard by which such an injury can be justly compensated, or even approximately measured. Easily simulated and impossible to disprove, it falls within all of the objections to speculative damages . . That damages so imaginary, so metaphysical, so sentimental, shall be ascertained and assessed by a jury, with justness, not by way of punishment to the defendant, but as mere compensation to the plaintiff, is not to be expected."

In so far as Street's pronouncement involved a prophecy it has come true only in part. Mental distress is still not an independent basis of liability in negligence actions but the elimination of the sequirement of "contact" leads to that result.

${ }^{16}$ Southern Pac. Co. v. Guthrie, I86 F. 2d 926 (9th Cir. I95I) discussed in the text infra.
} 
to whim would appear to call for a fairly convincing rationalization. The reasoning often used is that plaintiff has in fact suffered "something," an injury, and defendant, a wrongdoer, should not be excused merely because this something has no determinable monetary equivalent. This reasoning does not necessarily rest on a premise of punishment. The fault of the defendant is pointed to in order to justify compensation for the plaintiff's loss and particularly to counter the suggestion that the law should not make a finding for which there is no standard of judgment. It is the defendant, the argument runs, who has created the predicament. He cannot complain.

But why we may ask should the plaintiff be compensated in money for an experience which involves no financial loss? It cannot be on the principle of returning what is his own. Essentially that principle rests on an economic foundation: on maintaining the integrity of the economic arrangements which provide the normally expectable basis for livelihood in our society. Pain is a harm, an "injury," but neither past pain nor its compensation has any consistent economic significance. The past experience is not a loss except in so far as it produced present deterioration. It will be said, however, that these arguments betray a limited, a Philistine view of the law's concern, one that the law has happily transcended. This objection mistakes the argument. Of course the law is concerned, and properly so, with other than economic interests. The criminal law and the tort law in so far as punitive (that is to say in so far as the conduct of the plaintiff warrants punishment) is much concerned with the protection of non-economic interests; and to punishment may be added judicial remedies of a preventive character such as the injunction against nuisances, invasions of privacy, etc, and legislative devices such as zoning.

I am aware, however, that though the premise may elude detection, some deep intuition may claim to validate this process of evaluating the imponderable. One who has suffered a violation of his bodily integrity may feel a sense of continuing outrage. This is particularly true where there has been disfigurement or loss of a member (even though not giving rise to economic loss). Because our society sets a high value on money it uses money or price as a means of recognizing the worth of non-economic as well as economic goods. If, insists the plaintiff, society really values my personality, my bodily integrity, it will signify its sincerity by paying me a sum of money. Damages thus may somewhat reestablish the plaintiff's self-confidence, wipe out his sense of outrage. Furthermore, though money is not an equivalent it may be a consolation, a solatium. These arguments, however, are most valid for disfigurements or loss of member giving rise to a continuing sense of injury. (And in such cases there may be potential economic injury which cannot be established.) It is doubtful that past pain figures strongly as present outrage. And even granting these arguments there must be set over against them the arbitrary indeterminateness of the evaluation. Insurance aside, it is doubtful justice seriously to embarrass a defendant, though negligent, by real economic loss in order 
to do honor to plaintiff's experience of pain. And insurance present, it is doubtful that the pooled social fund of savings should be charged with sums of indeterminate amount when compensation performs no specific economic function. This consideration becomes the stronger as year after year the amounts set aside for the security account become a larger proportion of the national income.

It is not supposed, however, that even were the reasons of the best-and mine I am sure will fail to satisfy many-the courts will forthwith deny the right of the plaintiff to have these intangibles valued. But putting aside for the moment their bearing on legislation, I would suggest that they are not irrelevant to the judicial creation of new remedies and new items of damage; nor to the judicial administration of present items of damage.

A wry history of the attempt to measure-to "quantify" as the English judges have it-the immeasurable is found in a group of English cases dealing with damages for "the loss of expectation of life." In Flint $v$. Lovell ${ }^{16}$ the plaintiff, a "more or less wealthy" man of 70 , had been negligently injured and his expectation of life shortened by 8 years (as it then seemed). ${ }^{17}$ He was given only a year to live. The trial court awarded him $£ 4000$ for the loss of " 8 years of pleasant living." In 1937 the meaning of this decision was tested in Rose v. Ford. ${ }^{18}$ Mabel Rose, a young woman of 23 , was negligently injured, became unconscious almost at once, and died four days later. An action was brought by her administrator under the Law Reform Act of 1934 which for the first time provided for the survival of an action of a deceased. A majority of the judges of the Court of Appeal thought that Flint $v$. Lovell was inapplicable because Miss Rose was never aware that her expectation had been shortened. If damages were to be awarded they agreed that frooo would be a fair amount. But the House of Lords would not have it so. The action was for such damages as Miss Rose could have collected had she lived. Said Lord Wright, "A man has a legal right that his life should not be shortened by the tortious act of another. His normal expectancy of life is a thing of temporal value. . .."19 The Lords were not unaware of the difficulty of the task. Damages should be assessed in "a moderate way." The jury should use "common sense" and give "what is fair and moderate, in view of all the uncertainties and contingencies of human life. Special cases may occur, such as that of an infant or an imbecile or an incurable invalid or a person involved in hopeless difficulties."20

10 [1935] I K. B. 354. Sir Frederick Pollock commenting on the case at the time (5I L. Q. R'Ev. 268 (1935)) asserted that though "the expectation of life is a thing of temporal value" and the loss of it an admissible element of damage, one cannot say that the shortening of one's own life is a detriment. ". . . it is not possible for any human tribunal to attach any definite meaning to the term or, for that matter, to say whether death, when it happens, is in itself a bad or a good thing."

This distinction would probably have made no difference in Flint $v$. Lovell, but it would be pertinent to Rose v. Ford, [1937] A. C. 826 , when the injured person was unconscious from the time of injury to the time of death. Pollock doubted whether in any case damages should be awarded on this head since there was a danger that the plaintiff would be twice compensated for the same detriment.

${ }^{17}$ The prognosis was made sometime in I934. As appears in Rose v. Ford, [1937] A. C. 826, he was still alive in June of 1937. Of course, he would still have suffered the anticipation of death, but Rose v. Ford makes clear that that is not the element being "quantified."
${ }^{18}$ [1937] A. C. 826 .
${ }^{19} \mathrm{Id}$. at 848 .
${ }^{20}$ Id. at 850 . 
But the trial judges thereafter were somehow unable to discover what the common sense of England was on this head. Was compensation to be in direct proportion to life expectancy? Was the loss more heavy to the rich than to the poor? Verdicts ran from $£ 90$ to $1200 £$. And in 1940 the House of Lords had to be called in to pronounce the dictates of common sense concerning the value of varying intervals of life's term. ${ }^{21} \mathrm{~A}$ trial judge had awarded $f_{0}$ r200 for the loss of expectancy of a $2 \frac{1}{2}$ year old infant who had been instantly killed. It appeared to him that the infant had lost at least as much as Miss Rose. The Court of Appeal refused to disturb the verdict, one of the judges because the problem set was insoluble. He could not say $f_{\mathrm{x}} 200$ was wrong since he had no idea what the proper figure was. Goddard, L. J., was for reducing the figure to $£ 350$. Lord Chancellor Simon, writing for the House of Lords, thought the problem "more suitable for discussion in an essay on Aristotelian ethics than in the judgment of a Court of law, but in view of the earlier authorities, we must do our best to contribute to its solution."22 Then followed much talk about the factors of happiness and unhappiness, youth and age, the risks and uncertainties of childhood. In this linguistic alembic by a process almost alchemical the Lords arrived at the conclusion that $\oint_{200}(!)$ would be "a proper figure." The opinion concludes with a gentle warning (common sense having proved unreliable) "I trust that the views of this House . . . may help to set a lower standard of measurement than has hitherto prevailed for what is in fact incapable of being measured in coin of the realm with any approach to real accuracy."23

Nowhere in this whole history is there the glimmer of a suggestion of the social function which is served by undertaking this task "more suitable for discussion in an essay on Aristotelian ethics." Lord Wright felt called upon to vindicate the propositions that a man has a "legal right" not to have his life shortened tortiously and that life expectancy is a thing of "temporal value." And if as Flint v. Lovell held a man still alive could recover for the loss of expectancy (a somewhat more appealing proposition since here there is at least the motive of a solatium for future woe), the survival statute should be read as requiring recovery despite death.

The difficulty is certainly not entirely of the court's making. The survival statutes are themselves the product of an abstract rationalistic reform movement that continues to operate in the field of torts without regard either to the present problem or the present trend in solving it. These statutes are passed to abolish the "outmoded" "arbitrary" rule that personal actions do not survive the death of either party. It does not of course require any great perspicuity to perceive that the distinction pursuant to which contract actions survive and tort actions do not is "arbitrary" at least as generalization. The reasons may be historical ones not clearly understood ${ }_{9}^{24}$ perhaps irrelevant if they were. It is not, to paraphrase Holmes, a

\footnotetext{
${ }^{21}$ Benham v. Gambling [1941] A. C. $157 . \quad{ }^{22} I d$. at $166 . \quad{ }^{23} I d$. at 168.

${ }^{24}$ See Winfield, Death As Affecting Liability in Tort, 29 Cor. L. Rev. 239, 244, 250 (1929). In a broad sense the explanation of the distinction may be rather simple. Originally personal actions were thought of as resting in personal obligation between plaintiff and defendant. They were non-
} 
sufficient reason to deny a valid claim that the law was so in the time of Henry IV but neither is it a reason to create a new cause of action that it will eliminate a distinction which is no longer understood. The satisfaction of the theorists' desire for elegant jurisprudence should not be purchased with other people's money.

There is no room here to study and criticize the unutterable confusion of statutes in each state where the deceased has come to his death as a result of negligent injury. What is needed first is an inventory of the legitimate claims which arise by reason of death. There can be no thought that the arrangements will be thoroughly logical in terms of any one rationalization. In my opinion the basic rationalization is to satisfy the legitimate economic expectations which have been defeated. In some cases death will be a windfall because a fund will be provided that the deceased could never himself have amassed. In other cases recovery will fall short. In addition to expectations of long term support which have been defeated, there may be losses to those who had claims against the deceased because the suddenness of death will have prevented the deceased from making expectable security arrangements. It may in short be difficult to evolve precise formulas which provide for all legitimate economic claims. But I cannot think that putting it to a jury to evaluate "pain and suffering" or the loss of the expectation of life is a rational approach to the problem. It means for one thing that the interest of creditors, heirs, and dependents is made to turn on the particular way in which deceased came to his death.

If it is said that these vague formulas are used to assuage the feelings of pain and outrage of the living relatives, we are back again to the question whether these are proper items of compensation under the present conditions of liability. This is in some measure the question in another class of cases-those dealing with the death of small children. In at least one recent case ${ }^{25}$ damages were awarded for the death of a viable foetus. The case is thought to be the occasion for high jurisprudential speculation as to when and whether a foetus becomes a "personality." "... [I]t is but to deny a palpable fact to argue that there is but one life and that

assignable and did not pass to representatives. Exceptions were made by statute or decision as need or justice appeared to require. Such considerations were less exigent in the type of offense which was peculiarly personal, i.e., which was an invasion of the plaintiff's personality. Heirs might expect to inherit the deceased's real and personal property intact but what was personal to the deceased would inevitably vanish with him.

${ }_{25}$ Verkennes v. Corniea, 229 Minn. 365,38 N. W. $2 \mathrm{~d} 838$ (1949). The court admitted that its ruling was against the great weight of authority. Indeed there appears to be almost no support for it. See ro A. L. R. 2d 639 (I950).

A very different question is whether a living child can recover for pre-natal injuries. For some time the dominant view was against recovery based on Drobner v. Peters, 232 N. Y. 220,133 N. E. 567 (r92I). The current authority is moving in the other direction: Woods v. Lancet, $303 \mathrm{~N}$. Y. 349 , ro2 N. E. 2d 69I (I95I), overruling, Drobner v. Peters; Damasiewicz v. Gorsuch, 79 A. 2d 550 (Md. I95I); Tucker v. Howard I. Carmichael \& Sons, 208 Ga. 20I, 65 S. E. 2d 909 (I95I); Williams v. Marion Rapid Transit, 152 Ohio St. II4, 87 N. E. 2d 334 (I949). But see Bliss V. Passanesi, 326 Mass. 46r, 95 N. E. $2 d 206$ (1950); Drabbels v. Skelly Oil Co., I55 Neb. 17, 50 N. W. 2 d 229 (I95I).

It is a measure of the reasoning in the Verkennes case that it relied on cases allowing a living child to bring damages for pre-natal injury. In the opinion of the court the question was whether the viable foetus was a person. 
the life of the mother." But essentially the question is whether social justice dictates the compensation of the severe emotional distress in the loss of a child. Either general death or special statutes provide for compensation for the death of a minor child in terms of "pecuniary loss" or dependency. The most common element is the net loss to the parents from the loss of services of the decedent during minority. A strict adherence to this element would in many cases result in a denial of recovery. Where the child is still young costs of nurture will exceed the value of any expectable services; and in many families very little in the way of services will ever be demanded or expected. Yet it has been said that some pecuniary loss is presumed. ${ }^{26}$ Otherwise it is argued, the statute would be rendered "nugatory."27 One can only wonder what this means. If the purpose of the statute is to punish fault the observation is just but not if it is to compensate pecuniary loss. In judicial reactions of this sort we have strong evidence of the prevailing institutional confusion in the compensation of personal injury. One, of course, should expect a "skew" at this point. The death of a minor child is not only one of the most excruciating of distresses but one which most easily evokes sympathy. Generosity vouches for the sincerity of the emotion. Through the lawsuit the experience of sorrow can be transmuted into a personalized struggle between right and wrong. The defendant, however minimal his misdoing, is the sacrificial scapegoat, his pelf is the pledge of our sincerity.

The recent case of Hitaffer v. Argonne $\mathrm{Co}_{0}{ }^{28}$ is another instance where decision is made to turn on a series of fashionable propositions quite divorced from their function in the current scene. There the court held that a wife could recover from her husband's employer for a negligent injury to the husband which disabled him from sexual intercourse. It has been the law that the hubsand can recover for the loss of "consortium," though usually as an element of loss of service. It has also been the law that both can recover for intentional interference. These propositions being so the court could see no reason for denying the wife recovery in a case of negligence. It pointed to the fact that women have been emancipated. It ridiculed the reasons given for the distinction, e.g., that the injury to the wife is indirect; that the husband's suit is based primarily on the loss of service whereas the wife does not have such an action. It expatiated on the "modern concepts of the marital

${ }^{20}$ See Van Cleave v. Lynch, Iog Utah 149 , I66 P. 2d 244 (1946), upholding a verdict of \$10,000 for death of a 6 year old boy, the court admitting that damages were primarily for loss of society, etc. and reviewing a number of verdicts in other cases, two of them for $\$ 15,000$.

In Couch v. Pacific Gas \& Electric Co., 80 Cal. App. 857, I83 P. 2d 9r (1947), a verdict of $\$ 27,500$ for death of a child of ro months was reduced to $\$ 15,000$ and allowed to stand.

In Immel v. Richards, 154 Ohio St. 54, 93 N. E. $2 d$ 474 (1950), the jury awarded $\$ 5,000$ for the death of a 9 months old child. The award was upheld, Taft, $J$., dissenting, on the ground that therc was no evidence from which to make such a finding in terms of the statute's criterion of "pecuniary injury."

In Checketts v. Bowman, 7o Ida. 463, 220 P. $2 d 682$ (I950), a verdict of $\$ 40,000$ for death of a child of 9 years was reduced to $\$ 20,000$ and allowed to stand at that. See infra for the interesting sequel to this case.

${ }^{27}$ Sweeten v. Pacific Power \& Light Co., 88 Wash. 679, I53 Pac. 1054 (1915).

${ }^{28}$ I83 F. 2d 81I (Dist. Col. 1950), cert. denied, 340 U. S. 852 (r950). 
relations." The wife is permitted to recover for a willful interference. If the loss of consortium is protected against willful interference it "must be predicated on a legally protected interest." And if it is "legally protected" it must equally be protected against negligent interference. To distinguish is "neither legal nor logical." But the law, of course, often distinguishes between willful and negligent interference as in the cases of emotional distress. An interest is protected only in so far as it serves a social purpose to protect it. When the act is willful the law may award damages for penal purposes. But more basically the law quite properly recognizes that a willful assault on the personality inflicts a far more serious blow. It is almost unthinkable that a court should reduce consortium to the bare element of the opportunity for sexual intercourse and pretend to see no basic difference of offense to the wife's interest between the incidental loss of that opportunity and the deliberate destruction of the whole marital relationship.

More persuasive is the argument that since the husband has an action, so should the wife. But his action is a fossil from an earlier era. It is one of a group of archaic actions based on the notion that the paterfamilias was alone competent to sue for losses suffered by the family unit. The husband was entitled to his wife's service and this included the sentimental elements of her person and presence. The law did not seek to set a value on consortium ${ }^{29}$ as such. When to the husband's action, there is now added the wife's action for negligent injuries (which being emancipated she is entitled to bring) there is a danger of duplicating elements of damage. Ingenious efforts must be made to disentangle from the wife's recovery the constituents of the husband's cause of action. Indeed, the emancipation argues for the restriction or abolition of these actions rather than their extension. Some courts have been bold enough entirely to abolish the husband's action; ${ }^{30}$ and one has restricted the husband to the loss of services previously enjoyed, refusing to allow loss of consortium to be valued in either direction. ${ }^{31}$ It is still no doubt an element of recovery that the plaintiff has been incapacitated for intercourse; ${ }^{32}$ but in any scheme of compensation, impairment of function presents a stronger claim than the sorrow or disappointment of relatives and friends.

It was argued also in the Hitaffer case that the compensation act was intended to cover the entire obligation of the employer arising from the employee's injury. This argument has since prevailed in three jurisdictions ${ }^{33}$ and had the court been troubled simply by the formal inequality of husband and wife it might be thought

\footnotetext{
${ }^{20}$ See the excellent opinion in Marri v. Stamford Street R. R., 84 Conn. 9, 78 A. 582 (r9Ir).

${ }^{30}$ Marri v. Stamford Street R. R., stupra note 29; Bolger v. Boston Elevated Ry., 205 Mass. 420, 9 I N. E. 389 (rgro); Helmstetler v. Duke Power Co., 224 N. C. 82 I, 32 S. E. 2d 6II (r945).

${ }^{31}$ Felton v. Wedthoff, 185 Mich. 72, I5I N. W. 727 (1915).

${ }^{32}$ But in Felton $v$. Wedthof, supra note $3 \mathrm{x}$, where a husband had been hospitalized, the court refused to permit a valuation of the separation from his wife. The court said rather broadly that loss of consortium would no longer be valued. It appears to be a well-established doctrine in the federal courts that diminutions of family pleasures, e.g., ability to play with one's children, are not compensable and, therefore, it is error to put in evidence that one has a wife or children. See Slattery v. Marra Bros., I 86 F. 2d I34, 137 (2d Cir. I95\%).

${ }^{32}$ Bevis v. Armco Steel Corp., 156 Ohio St. 295, I02 N. E. 2d 444 (I95I); Napier v. Martin, 250 S. W. 2 d 35 (Tenn. 1952); Guse v. A. O. Smith Corp., 260 Wis. 403, 51 N. W. 2 d 24 (1952).
} 
that it would have gladly taken this way out. But says the court, ". . . it would be contrary to reason to hold that this Act cuts off independent rights of third persons.... A brief examination of it will reveal that there is no provision therein for compensating a spouse for the loss of consortium." ${ }^{34}$ A somewhat less brief examination of the statute will reveal that the interests of spouse and children are within its ambit. The statute has in mind the husband or the wife as the head of a family or as one having dependents.

One journal approving Hitaffer v. Argonne Co. has this to say: $:^{35}$

Courts are living in a practical world and must recognize the facts of life. Here was a healthy man, living with his wife and enjoying normal sexual relationships. Along comes an employer who by negligence makes those sexual relationships impossible.

In this statement we have a striking and illuminating example of the playing of both ends against the middle which is characteristic in this field. When the question is proof of negligence every argument is mustered to eliminate a requirement that negligence be proved in a sense that would support a finding of moral delinquency. It is emphasized that the action is compensatory rather than punitive. As we have seen, Professor James' thesis of "accident proneness" attempts completely to destroy the frame of moral reference. The more usual insistence on negligence as the departure from the objective "standard" moves in the same direction. The availability of insurance makes it increasingly difficult to insist on the relevance of the standard of due care. The most trivial departures from an assumed standard serve to move the case past the judge to the jury. Once the propriety of this approach to the question of liability is insisted upon it is disingenuous to place much weight on fault as a specific factor justifying damages.

The above quotation particularly emphasizes the point. In its subtly anthropomorphic version of the employer it is doubly disingenuous. Employers in these times almost never "come along," because they are corporations. It is a fellow employee who has been negligent. There will be some who read this assertion with horror; it may appear to revive the unhallowed spectre of the "fellow servant rule." And it will be asked, too, whether the author has ever heard of respondeat superior. Holmes, it will be recalled, ${ }^{36}$ thought that the doctrine of respondeat superior was a mere remnant of patriarchal notions of identification, survival of a time when wife, child, and servant were in "the power" of the husband, father, and master; when indeed the servant was a slave without personality, forfeitable if he injured another as a noxious thing which the master by paying could redeem. Amazingly Holmes could find no reason or basis in modern law for charging an employer with

34 183 F. $2 \mathrm{~d}$ at 820 .

${ }_{50}^{35}$ NACCA L. J. 201 (1950) (italics supplied). Cf. the indignation expressed in 8 NACCA L. J. II9 (195I), over a decision denying damages under FELA to the non-dependent adult children of a negligently killed worker: "To allow a railroad, negligently killing a father, to escape all liability ... is unjust. .... Had the railroad killed a valuable hunting dog, substantial damages would be allowed. "NACCA hopes some day that the courts will find a way of compensating adult, self-supporting children; or that Congress will so order by an amendment to the FELA." To what end?

${ }^{30}$ Agency, 4 Harv. L. Rav. 345, 5 HARv. L. Rev. I (1891). 
the employee's torts. If by that doctrine one seeks to prove that the employer is a tortious wrongdoer he would indeed be invoking a fiction of identification. ${ }^{37}$ But it is now common ground both that the doctrine involves no fiction if correctly understood and that it is perfectly sound and desirable. The entrepreneur liable for his employee's negligent act is charged not because he "came along" but because he assumes to embark upon an enterprise creating certain risks for which he may make provision. Because he is in this position he is better able than the injured party to bear the loss. It would be an anachronism, no doubt, to suppose that the doctrine arose or was initially preserved in response to so explicit a formulation. Yet is one not entitled to suppose that some such ideas were dimly felt long before they were expounded? In any case this is its rationalization for our times; this is its function. When we put the situation thus, it is no longer open to us to justify an award to the wife on the premise that she has been victimized by the employer corporation. We must ask, rather, whether placing a money value on this sorrow serves a sufficiently valuable function to make it a legitimate charge against the national insurance funds.

Some of this same confusion, incidentally, is found in the cases dealing with recoveries by plaintiffs for items of damage which they would have suffered had they not been insured or had they not been the recipient of a gift. In the early New York case of Drinkwater $v$. Dinsmore ${ }^{38}$ the plaintiff injured by the servants of the defendant was denied damages for loss of wages because his employer had voluntarily paid them. "This was not a case for exemplary damages," said the court. "The plaintiff was entitled to recover, in addition to what a jury might award him for his suffering and physical injuries, only his pecuniary loss." ${ }^{39}$ This appears a sensible view, but it has been nearly universally condemned. ${ }^{40}$ It is said to relieve the "wrongdoer" from the consequences of his wrong, to give him a windfall. In the minds of those who thus argue it is as if the negligent act had some specific monetary dimension of wrongfulness ${ }^{41}$ rather than simply providing the basis for

\footnotetext{
${ }^{37}$ In some jurisdictions penal damages may be awarded against the corporation for the misconduct of a servant however lowly. See McCormick, Damages 285 (1935).

In an interesting recent case, Haser v. Pape, 50 N. W. $2 d 240$ (N. D. I95I), a taxicab company was held liable for rape committed by a driver. On the first trial a verdict of \$ro,000 was returned against the driver (verdict directed in favor of taxicab company). On reversal of the direction in favor of the company a retrial against the company alone resulted in a verdict of $\$ 650$. This the trial judge set aside as inadequate and his ruling was sustained. In a subsequent suit against the company's insurer on the $\$ 10,000$ verdict against the driver it was held that provisions in the insurance contract excluding liability for positive misconduct would be effective at least in so far as the liability of the driver was concerned. The question was left open as to whether it would exclude liability of the company, since it was under a statutory duty to insure. Haser v. Maryland Casualty Co., 53 N. W. $2 d$ 508 (N. D. 1952).

${ }^{38} 80$ N. Y. 390,36 Am. Rep. 624 (I880). $\quad{ }^{30}$ Id. at 392, 36 Am. Rep. at 625.

10 See Landon v. United States, x97 F. $2 \mathrm{~d}$ I28 (2d Cir. I952). A note however in 63 Harv. L. Rev, 330 (1949), takes the view proposed in the text. It points out that the majority doctrine confuses a penal with a compensatory view. And at 337 it states more broadly "... if the ultimate cost of certain torts or breaches of contract is to be paid by society, the rules of damages must be readjusted."

"Sec, e.g., Campbell v. Sutliff, I93 Wis. $370,374,214$ N. W. 374, 376 (1927), where the court talks about the "wrongful acts of the tort-feasor" and states that "the extent of the liability of the wrongdoer is dependent upon the extent of the injuries inflicted by his wrongful act. . .." Yet here not the defendant but his servants were negligent.
} 
the plaintiff's well-being. Where the plaintiff's pay or hospitalization is insured or guaranteed by contract there is an argument that a deduction would deprive the plaintiff of a contractual interest for which he has paid and give the defendant the benefit of something for which he had not paid. ${ }^{42}$ Even here an appropriate statutory scheme would require the defendant to pay the insurance fund and thus reduce the insurance cost rather than give the plaintiff a double recovery; and this is the principle which now generally prevails in workmen's compensation and fire insurance.

We have so far been dealing with substantive problems. Let us turn for a moment to judicial administration. In Affolder v. New York, C. \& St. L. R. R., ${ }^{43}$ the plaintiff, 35 years of age, lost his leg. He had been earning $\$ 400$ per month; he had an expectancy of 37 years. He suffered pain and could be expected to suffer further pain; he would need more surgery. He would need an articifical limb of a special type. The jury awarded him $\$ 95,000$. The trial judge reduced the verdict to $\$ 89,000$. He calculated a 60 per cent loss of earning power for a total loss of $\$ 70,000$. He compared other cases dealing with loss of leg. There should, he thought, be some uniformity. In $x 944$ a verdict of $\$ 60,000$ had been reduced to $\$ 40,000$. $^{44}$ No one, admitted the judge, can evaluate "with any degree of accuracy what amount of money will compensate plaintiff for the pain and suffering he has sustained" but "we cannot escape the belief in this case that the sum agreed upon by the jury exceeds what has heretofore been determined to be a fair sum." remittitur was made. On appeal by the railroad the court said, "The assignment of error that the verdict is excessive is not properly addressed to this court."46 And finally the Supreme Court said, "We agree with the Court of Appeals that the amount of damages awarded by the District Court's judgment is not monstrous. ..."

This word "monstrous" is the only recent contribution of the Supreme Court to a question which has split the federal courts of appeals for some time. ${ }^{48}$ Most of them hold the doctrine that a court of appeals is without authority to review a claim that damages are "excessive." ". . . the amount of a verdict is primarily a

\footnotetext{
42 The note writer in 63 Harv. I. Rev, stupra note 40 , argues that even so the insurance is not a saving but a purchase of security. Would a completely logical view be to charge the cost of premiums to the defendant?

${ }^{43} 79$ F. Supp. 365 (E. D. Mo. I948).

«See Cunningham v. Pennsylvania R. R., 55 F. Supp. Iorz (E. D. N. Y. 1944).

79 F. Supp. at 370.

${ }^{10} \mathrm{New}$ York, C. \& St. L. R. R. v. Affolder, 174 F. 2 d 486,493 (8th Cir. 1949).

${ }^{47}$ Affolder v. New York, C. \& St. L. R. R., 339 U. S. 96, ror (1950). The court of appeals, however, had not so characterized the reason for its ruling.

${ }^{18}$ Southern Ry. v. Bennett, 233 U. S. 80,87 (1914) is authority for the proposition that "a case of mere excess upon the evidence is a matter to be dealt with by the trial court. It does not present a question for reexamination here upon a writ of error." (Italics supplied.) It has been thought that this limitation on the power of the appellate court may have arisen from the fact that on writ of error only the judgment roll came up and that under the old practice the record thus did not contain motions for new trial or the rulings on them. Hand, $J$., in Miller v. Maryland Casualty Co., 40 F. $2 d$ 463 (2d Cir. 1930); but Brandeis, J., in Fairmount Glass Works v. Cub Fork Coal Co., 287 U. S. 474 (1933) explains that the writ of error is no longer restricted and if the appellate court cannot pass on a claim of excess it is now for other reasons.
} 
factual evaluation on inabsolute elements, while our function has been regarded as extending only to a testing of the soundness of the processes by which such a result has been achieved."49 Motions to set aside a verdict as excessive are to be addressed solely to the discretion of the trial judge. Courts that hold to this view, however, may point to an excessive verdict as showing that error has been prejudicial. $^{\text {50 }}$ And it is generally said that an excessive verdict may suggest the influence of "passion and prejudice"; however, courts are hesitant so to convict a jury unless counsel has interjected elements of passion and prejudice. The fourth and ninth circuits, however, claim a limited authority to review "excessiveness as such."51 In the recent case of Southern Pacific Co. v. Guthrie ${ }^{52}$ the verdict was for \$I00,000. The court of appeals was of the opinion that no more than $\$ 60,000$ of this was attributable to loss of earnings, though conceivably the jury's calculation of loss of earnings was $\$ 70,000$. This left $\$ 40,000$ for intangibles. This verdict said the court was "too high." But does the court of appeals have power ever to order a remittitur? "Yes," said all except one member of the court. The Affolder case was thought to imply such a power..$^{53}$ But said a majority of the judges the power could be exercised only if the verdict was "monstrous" which interpreted means "grossly excessive"; and \$40,000 for pain and suffering was not "grossly excessive." With this conclusion three of the judges disagreed. In Denman's opinion if the amount is "substantially" more than appellant should pay it is a denial of justice to make him pay; he is being required to pay more than he "owes." S44 Said Stephens, J.,"

I cannot go along with the so-called "monstrous" doctrine. It seems to me that by adopting it we give up all attempt to square the judgment with a reasonable basis for its support. I would think a million dollar judgment for the loss of a little finger would be monstrous (though I have none to sell at that figure) but I don't know about a ten or twenty thousand dollar judgment. . . . I cannot believe that our system of jurisprudence places everybody's material fortune, such as our free enterprise enables us to accumulate, at the unbridled whim of any twelve men and women. . . .

${ }^{\text {so }}$ See St. Louis Southwestern Ry. v. Ferguson, 182 F. 2d 949, 954 (8th Cir. 1950). In Fairmount Glass Works v. Cub Fork Coal Co., 287 U. S. 474 (1933), Brandeis, J., noted (at 485) "This Court has frequently refrained from disturbing the trial court's approval of an award of damages which seemed excessive or inadequate, and the circuit courts of appeals have generally followed a similar policy. Whether refusal to set aside a verdict for failure to award substantial damages may ever be reviewed on the ground that the trial judge abused his discretion, we have no occasion to determine." (The Fairmount case dealt with an inadequate verdict.)

${ }^{50}$ St. Louis Southwestern Ry. v. Ferguson, supra note 49 . Here plaintiff's counsel improperly suggested to the jury that defendant had sought to suppress evidence, etc.

${ }^{51}$ Cobb v. Lepisto, 6 F. 2 d 128 (9th Cir. 1925); Virginian Ry. v. Armentrout, I66 F. $2 d 4^{00}$ (4th Cir. 1948).

62 186 F. 2d 926 (9th Cir. I95I), cert. denied, 34I U. S. 904 (195I).

${ }^{53}$ The eighth circuit (whose decision was reviewed in the Affolder case) expresses doubt whether that case meant to imply a power to review for excessiveness. St. Louis Southwestern Ry. v. Ferguson, r 82 F. 2d 949 (8th Cir. 1950). But in Missouri-K-T-R Co. of Texas v. Ridgway, rgr F. 2d 363 (8th Cir. I95I) the court said that whether the verdict was "monstrous" it need not decide; it was however "so excessive as to shock the conscience." On that basis it held that certain improper appeals to the jury by plaintiff's counsel were reversible error; even that stops short of reducing a verdict simply because excessive.

is $86 \mathrm{~F} .2 \mathrm{~d}$ at 933.

65 Id. at 934 . 
The following year a division of the ninth circuit ${ }^{56}$ did hold that a verdict of $\$ 35,000$ for the death of an 8 year old son was "monstrous" and ordered a remittitur of $\$ 15,000.57$

This difference between the courts of appeals is probably one of degree. The Supreme Court's epithetical "monstrous" implies that a verdict may be so large that a refusal to set it aside is an abuse of discretion. It is in the nature of the problem that it is almost impossible to give further character to the notion of "monstrous" or "grossly excessive." Perhaps the touchstone is initial shock and astonishment that a jury could so decide or a belief that juries generally would have given far less. Perhaps it is the ratio between the economic loss and the award for intangibles. It is enough for some of the judges of the ninth circuit that the verdict is very much larger than it "should" be; and that the defendant is thereby being required to pay more than he "owes"; there is in this form of rationalization an implication of an absolute touchstone which, I am afraid, will elude detection.

What is clear, I think, is that the majority approach to the problem of appellate control tends toward the progressive maximization of damages. This statement may appear to be a truism, since in any one case the refusal of the appellate court to intercede will always mean that damages are not reduced. But it would be at least logically possible for a trial judge to control damages as closely as an appellate body. Yet in fact we would not expect that to happen. The trial judge is subject to the same influences as the jury: the presence of the plaintiff in the courtroom, the dramatization of his predicament, the impersonality of the defendant, so often incorporated or insured or both. And the trial judge is further influenced by the jury itself. He has established a personal relation with them. He may not wish to appear either to them or to himself less generous, less understanding, or less sympathetic. These factors, in my opinion, point toward the soundness of the attitude expressed by the ninth circuit judges in Southern Pacific Co.v. Guthrie. There may be no absolute basis upon which the appellate judges can exercise their control but they can introduce an element of measure and uniformity, a particularly desirable objective in an area of insurability.

I suspect that underlying the somewhat confused and latitudinarian judicial approach in these damage matters is the contingent fee. It is clearly established in this country that lawyers' costs are not recoverable by the winning party. As long as this is true, plaintiff's recovery will be reduced from 20 per cent to $5^{\circ}$ per cent. Thus, however carefully calculated the plaintiff's economic loss, the plaintiff's "take-home" may be substantially less. No court without working a drastic change in the law can overtly make an allowance for the lawyer's fee. But until our system of com-

${ }^{50}$ Two of three were Denman and Stephens.

${ }^{67}$ Covey Gas \& Oil Co. v. Checketts, 187 F. 2d 561 (9th Cir. 195I). The case had involved what Denman characterized as "forum shopping." The plaintiff had first procured a judgment of $\$ 40,000$ in the state court of Idaho; the Idaho Supreme Court had ordered a remittitur of $\$ 20,000$. Checketts v. Bowman, 70 Ida. 463,220 P. $2 \mathrm{~d} 682$ (I950). It is interesting that the two juries awarded $\$ 40,000$ and $\$ 35,000$ respectively, showing, perhaps, that there is a lay sense as to how such matters should be evaluated. 
pensation achieves a somewhat more rational form, the award for pain and suffering might be measured and justified in terms of a contribution to the real costs of the litigation..$^{58}$

The implication of these observations is that if our basis of compensating injury is shifted implicitly or explicitly from fault to insurability there must be a reconsideration of the kinds of interest which are compensated and the degree of compensation for the interests which are compensable. It seems likely that, as the goal becomes universal coverage of injury and disease, protection must tend to shrink toward the minimum level of economic loss. I have tried to show that in the absence of willful misconduct it is particularly difficult to justify damages for past discomfort. Impairment of function makes a stronger claim. If we turn to a statutory insurance scheme, workmen's compensation, we find that pain and suffering whether past or future is not compensated except as the existence of pain may produce partial or total disability to earn. ${ }^{59}$ Most statutes, however, contain a schedule of specific injuries for which compensation is fixed by statute. Even though the workman is able to resume employment without loss of wages, he recovers the fixed payment. ${ }^{60}$ The probabilities, however, are overwhelming that injuries included in the schedule will result in losses of earning power which may not be demonstrable. A man will often be kept on the payroll despite an injury but should the maimed individual have to go elsewhere his disability may be an obstacle. This is particularly true of disfigurement which is compensable under many statutes. $^{61}$ But the intention of the statutes is carried further and held to cover

${ }^{68}$ Cf. MCCornuck, Damages 277 (1935): "Another substantial argument for exemplary damages in the present American procedural system is that the award of such damages remedies, though crudely and in only a limited class of cases, one of the glaring defects in our system, which is the denial of compensation for actual expenses of litigation, such as counsel fees, to one who has been forced by a wrongdoer to establish by litigation the justice of his claims."

${ }^{50}$ In Cornell-Dubilier Elec. Corp. v. Manocchia, 89 A. 2d 923 (R. I. I952) the worker contracted a skin disease. It was held that as long as the disease was uncured and the discomfort and embarrassment of working might retard recovery, the worker might remain away from work and recover for temporary total disability. A dictum stated that once cure was effected, embarrassment was not compensable.

${ }^{\circ 0}$ Bednar v. Ingersoll Rand Co., 279 N. Y. 80, r7 N. E. 2d 777 (1938) (one quarter loss of hearing in one ear; no loss of earnings shown); Florick v. Broad Window Cleaning Co., 243 N. Y. 576, 154 N. E. 6II (1926); Cameron Coal Co. v. Dunn, 85 Okla. 219, 205 Pac. 503 (I922).

o1 N. Y. WORK. CoMp. LAW $\$ 15(t)$ (facial disfigurement; amount discretionary up to $\$ 3500$ ); Laws of Mass. c. I52 $\S_{36 \mathrm{I}}(\mathrm{h})$ (bodily disfigurement; amount discretionary up to $\$ 2500$ ).

N. M. Stat. AnN. 57-918(b) 1941 “. . . If any workman is seriously permanently disfigured about the face or head the court may allow such additional sum . . . as it may deem just." In Elkins v. Lallier, 38 N. M. 316, 32 P. 2d 759 (1934), the claimant lost an eye. The schedule provided I0o weeks' compensation for loss of sight in one eye; I Io weeks for the eye itself. An award for Ioo weeks plus $\$ 75^{\circ}$ for disfigurement was sustained. The same result was reached in Donahue v. Adams Transfer \& Storage Co., 230 Mo. App. 215, 88 S. W. $2 d 432$ (1935).

Some statutes provide that there shall be no compensation for disfigurement, if compensation is payable for any other disability: IND. STAT. ANN. 40-I303(b)(7) (1952). In some recovery may be had if disfigurement constitutes a separate injury. ILL. STAT. ANn. c. I48, \$145(c) (1942); S. D. Code ANN. 64.0403(2) (1939). See Chicago Home for the Friendless v. Industrial Comm., 297 Ill. 286, I30 N. E. 756 (1921) (loss of hand and facial disfigurement); of. Smith-Lohr Coal Mining Co. v. Industrial Commission, 291 Ill. 355, 126 N. E. 164 (1920). In Oklahoma both may be had for the same injury. OkLA. Stst. Ann. tit. 85, 922 (1952). 
maimings where there is no known rationalization in terms of economic loss. The loss of one testicle has moved the judges to impassioned lyric utterance on the nature of man; ${ }^{62}$ it has been held compensable under a statute providing compensation "... where the usefulness of the member or any physical function is permanently impaired ..." or "as an injury known in surgery to be a permanent partial disability" or simply a "disability." I/ro of total disability and as such worth $\$ 800$.

It is a fact well publicized that the payments for maiming are much, much less than in a negligence action. It will be remembered that in the Affolder case the plaintiff, a man of 35 earning $\$ 400$ per month, lost his leg. The Court fixed his loss of earning capacity at 60 per cent. The jury awarded him $\$ 95,000$ which the judge reduced to $\$ 80,000$. Under the New York compensation statute which is one of the most liberal he would receive for the loss of a leg $2 / 3$ of his weekly salary for 288 weeks or about $\$ 7,280 ; 60$ in Indiana where the injury occurred he would receive $\$ 11,000 ;{ }^{67}$ in Vermont he would receive $\$ 4250 .^{68}$

There is then in our system a vast discrepancy between the compensation of an injury depending on whether one is employed by a manufacturer or an interstate railroad; or whether one's injury is work-connected or not. The logic of the situation points to a reduction of this discrepancy. It appears likely that a system which sets the economic loss of a worker at \$I7,280 will not see fit to allow four times that amount to one suffering a similar loss in an automobile accident. To be sure the negligence requirement, however formal, still does eliminate many claims so that it could be argued that more generous compensation is feasible. But as compensation has become more general the cost of insurance has been mounting rapidly and the present scheme of calculating damages will be on the defensive. ${ }^{00}$ Workmen's compensation schemes on the other hand are in many jurisdictions on a

${ }^{02}$ The opinion in Hercules Powder Co. v. Morris County Court, 93 N. J. 193, I07 Atl. 433 (1919) is the best known.

${ }^{03}$ Ibid.

${ }^{64}$ Kostida v. Dep't of Labor and Industries, 139 Wash. 629, 247 Pac. 1014 (1926).

${ }^{\circ}$ Carr v. John W. Rowan Plastering Co., 227 Mo. App. 562, 55 S. W. $2 d$ 723 (1932).

${ }^{\circ 0}$ N. Y. Work. Comp. Law, $\S \mathrm{I}_{5}(3)$. If there were "temporary total disability" bcyond 40 wecks he would reccive additional payments, $\$ 15(42)$, but perhaps not more than $\$ 5,000, \S 15(2)$.

${ }^{87}$ IND. STAT. $\$ 40-1303$ (Burns r952): two hundred weeks times 60 per cent of average weckly salary. In addition he may receive 26 weeks of temporary total disability (6o per cent of average weekly earning), i.e., \$1430. Under the New York law he would receive nothing for the first 40 weeks of temporary total disability.

${ }^{88}$ One hundred and seventy weeks times 50 per cent of his average weekly pay but a maximum of $\$ 25$ per week. He would also receive $\$ 25$ per week in addition during the period of total disability incident to the loss of the leg whereas under the New York law he would receive nothing for the first 40 weeks of total disability. Thus, he might receive an additional $\$ 1,000$, VT. STAT. $\$ \$ 8096,8102$ (1947), as amended by Pub. Laws 1949, No. I94.

${ }^{80}$ Material on the point is noted in McNiece and Thornton, Automobile Accident Prevention and Compensation, 27 N. Y. U. L. Rev. 585, notes 56, 57, and 93 (1952).

It is said that in New York City the cost of insurance is now equal to or grcater than the cost of motor fuel. There have been seven increases in the rates since World War II.

In Massachusetts losses have risen from $\$ 700,000$ in 1946 to $\$ 5,000,000$ in 1951 . The Massachusetts companies claim that they are losing money on this business and they asked for an increase of 22 per cent and were allowed 9.7 per cent. 
niggardly basis. Where weekly benefits are tied to weekly earnings the statute adjusts to inflationary movements but a great many of the statutes contain upper limits fixed in dollars which in time become obsolete and are changed only after considerable agitation. Another defect in many of the statutes is an absolute limit on the number of weekly payments in cases of total disability. The railroad unions have opposed the enactment of a compensation scheme in place of the FELA. It is argued that the present schemes of compensation are inadequate and unfair. It is argued that it is unfair to return the railroad workers to the statutes of their respective states with their wide varieties of inadequacy. Abstractly it would not seem unfair that railroad workers be subject to the same law as other workers in their respective states. But undoubtedly many of these statutes are unfair in themselves. Under the circumstances a federal statute generously devised would provide leadership.

In England all persons are now insured against injury and disease. The statute retains, in addition, actions based on negligence even against the injured person's employer, though 50 per cent of the insured benefit can be offset. It has been suggested both in connection with FELA and in automobile accident compensation schemes that as in the English system the negligence concept might be retained as an addition to a compensation scheme. Some have said that then negligence could be administered in a meaningful sense, requiring "real" fault or covering nontypical risks. But in appraising the impact and significance of the double basis in England it must be realized that the insured benefits are at a uniform minimum level taking no account of differences in earning capacity. Benefits for workconnected injuries are higher but even these benefits are modest by our standards; and the insured person must make a weekly contribution. ${ }^{70}$ The negligence principle should be retained, of course, to cover non-insurable risks. But it is a more arguable question whether negligence should be retained as a basis for additional compensation. We have shown that negligence as administered today does not signify seriously unsocial conduct. Our experience with degrees of negligence is not such as to lead us to believe that juries can make meaningful distinctions between minimal fault and "real" fault. Furthermore, such recoveries will, of course, be paid by insurance unless insurance for them is outlawed. The question still arises

${ }^{70}$ This scheme is financed by contributions from the insured person, the employer, and the state. National Insurance (Industrial Injuries) Act, 1946, 9 and 10 Geo. 6, c. 62; Family Allowances and National Insurance Act, 1952, I ELxz. 2, c. 29. The weekly injury benefit thereunder (temporary total disability) is 55 shillings ( $£_{2}$ I5s). For an injury resulting in disablement the benefit ranges from IIs for 20 per cent to 55 s for roo per cent with an addition of 20 s if beneficiary is incapable of work and likely to remain permanently so incapable. To these add ros. $6 \mathrm{~d}$. for a child or the oldest child and $21 s$. 6d. for a dependent spouse. Thus, if a worker is totally disabled, cannot work at all, and has a wife and child, he would receive, as I figure it, I07s ( $£ 57 \mathrm{s.}$.).

The benefits for non-work connected injuries will be found in National Insurance Act, I946, 9 and Io Geo. 6, c. 87 . The basic benefit is $26 \mathrm{~s}$.

The negligence action is governed by Law Reform (Personal Injuries) Act, 1948, Ir and 12 Gro. 6, c. $4 \mathrm{I}$.

See generally Friedmann, Social Insurance and the Principles of Tort Liability, 63 HARv. L. Rivv. $24 \mathrm{r}$, at 253 et seq. (I949). 
whether our insurance fund should bear these additional charges. Most of the defendants, too, will be corporate and there is little logic in charging them further for the negligence of their employees; it might still be argued that additional recovery should be permitted in cases of willful misconduct, or in cases where top management has failed to follow good engineering practice. ${ }^{71}$ The principal function of penalizing fault is, of course, preventive. And there is evidence that policing of the risk by insurers-which takes place without having additional liability for negligence-is a more effective preventive than the threat of liability (which is usually insured anyhow).$^{\mathbf{7}}$

A recent writer, Frank Grad, has pointed to the Saskatchewan auto accident compensation scheme as proof of the feasibility of providing a minimal compensation for all injuries while retaining the negligence suit. ${ }^{73}$ Under the scheme everyone injured by auto is insured by the state. The premiums are very low ${ }^{74}$ The benefits are modest compared even to our workmen's compensation schemes. ${ }^{75}$ The government also writes insurance against liability for negligence. In its first two years there were 6,306 claims, benefits amounted to $\$ 1,277,500 .^{76}$ Claims were quickly settled. There have been relatively few claims for additional compensation based on negligence. This plan then has worked very well in Saskatchewan. Basically it has probably resulted in a classification of injuries depending on their seriousness. Where the injury is small, the statutory compensation is accepted; where it is large a further claim is made and if one is fortunate enough to have been injured by a careless driver he recovers additional compensation. Such a classification whether logical or not may well promote "customer satisfaction."

Mr. Grad believes that the Saskatchewan experience has proved the general worth of the scheme. But at least certain questions arise as to its transferability to a jurisdiction such as New York. We would have to know the comparative accident rates. Saskatchewan is a rural, New York a dense metropolitan area. It will be noted, too, that the average recovery in Saskatchewan was $\$ 200$ per claim. Writers on this subject tend to overlook the fact that Americans think in comparatively extravagant terms. Our recoveries are amazingly large compared to those in other countries, justified up to a point, of course, by our greater wealth. Our recent writers and courts encourage, as we have seen, the disposition of juries to think in

${ }^{71}$ In Germany the employer is held only for willful misconduct, in Austria for gross negligence. See Lenhoff, Social Instrance Replacing Workmen's Compensation, 5 NACCA L. J. 49, 54 (1950).

Suggestions for limiting liability in the English scheme to gross negligence were rejected. Friedmanm, supra note 70, at 257. Degrees of negligence are apparently not popular with English lawyers. The English judges have said that "gross negligence is ordinary negligence with a vituperative epithet ..." See Grill v. General Iron Screw Collier Co., L. R. I C. P. 600 (1866) printed in Seavey AND KeEton's CAsES ON ToRTS.

${ }^{72}$ See James, supra note $I$, at 557 .

${ }^{73}$ Grad, Recent Developments in Automobile Accident Compensation, 50 CoL. L. Rev. 300 (1950).

74 The fund is provided by premiums on autos of $\$ 4.50$ to $\$$ ro.00 per year.

${ }^{35}$ Death benefits at $\$ 3000$ for a primary dependent, and for all dependents a maximum of $\$ 10,000$. Permanent total disability - a maximum of $\$ 20$ per week until $\$ 2400$ has been received.

Temporary total disability-a maximum of $\$ 20$ per week up to 52 weeks.

${ }^{78}$ See Grad, supra note 73 , at 323. 
generous terms. Our people grow increasingly "claim-conscious." This means not only that they press a claim when they have one. It means also that they have ample ideas of the magnitude of their injury and, further, that they are more imaginative in the attribution of their ailments to the conduct of insured persons. The concept of "insurability" expands the horizons of plaintiffs and juries. The ethical sense-or the sense of caution-becomes somewhat dulled in the presence of an impersonal insurance fund. This is, perhaps, one of the general problems of a "security state."

Writers recognize these facts but usually do no more than make a few pious caveats before ignoring them in their conclusion. The courts, it is said, have the power and perspicacity to expose fraud; they will demand adequate cogent evidence; they will curb the excesses of juries. But once rules of law concerning the elements of liability are established these asserted defenses against "abuse" are speedily forgotten. The current cliches about the sphere of the jury are ill-adapted to the task of curbing it; they express, furthermore, the general uncertainty as to what principles should prevail in this area. Even some of the judges, when they sit as triers of fact, think and feel as would the jury or seek to adopt its attitudes.

In a recent article McNiece and Thornton sum up many of the factors in the current situation: the high "claims consciousness" of New Yorkers, ${ }^{77}$ the tremendous increase in insurance rates. They are aware also of the great abuses of compensating psychic injury-the opportunity for simulation and (more common) attribution of preexisting neuroses to the defendant's conduct. ${ }^{78}$ ' Yet withal they impliedly advocate the abolition of the negligence requirement without dealing in any positive fashion with the mounting cost of insurance. They reject, for example, any notion of a schedule of fixed recoveries: ${ }^{99}$

${ }^{77}$ See notes 2 and 69, supra. Dickerson in his Products Liability and the Food Consumer (195I) at 249 offers evidence that out of 38,000 claims against insurers for food liability 67 per cent were from the New York Metropolitan area, 12 $1 / 2$ from Boston, and the remainder spread around the country!

In a recent year the " $X$ " grocery chain paid $\$ 14,000$ claims in New York, $\$ 8 \mathrm{r}, 000$ in Boston, $\$ \mathrm{I}, 500$ in Chicago, and none in Los Angeles. The same chain with 50 stores in Philadelphia had paid one claim in 9 years.

${ }_{78}^{8}$ Professor McNiece has treated very well the problems involved in compensation of psychic injury in his article, Psychic Injury and Tort Liability in New York, 24 ST. Jorns L. Rev. I (r949). He distinguishes between normal and idiosyncratic responses to stimuli and would allow very little recovery for the latter. Id. at 76 . He notes, however, that verdicts allow somewhere around $\$ 9,000$ for psychic diseases of either sort, laymen having been much oversold on the liability of the ordinary man to traumatic psychosis. Id. at 77 , note 254 .

I would agree with Professor McNiece though his position in some measure rejects the usual view that you "take the plaintiff as he is." See for example, Owen v. Rochester-Penfield Bus Co., New York Court of Appeals, Oct. 24, r952.

Professor McNiece says further, "Dangers of fabrication of evidence where they exist can be effectively combated by demanding clear and cogent evidence according to the best medical standards available." Id. at 81. Apropos of this suggestion, the Supreme Court in New York City has recently approved the establishment of a panel of physicians to examine plaintiffs in cases where the evidence is conflicting. The expert will be subject to call at the trial. This, said Judge Peck, should have a "psychological and prophylactic effect." N. Y. Times, Nov. 24, I952, p. I. It remains to be seen how such evidence will affect the attitude of the jury. Perhaps, however, as insurance rates mount juries will be more discriminating.

${ }^{70} 26 \mathrm{Sr}$. Johns L. Rev. at 274 . 
... the courts, trained as they are in dealing with the facts and equities of particular cases and having broad latitude in awarding damages, can more justly determine accident cases. . . .

It would seem to me that at least in industrial accidents we should retain our present scheme of compensation without the addition of a negligence suit against the employer. It is better to put the money into more generous compensation payments than into a capricious dividend based on the manner in which one's fellow servant happened to contribute to the injury. The automobile accident situation is more difficult and this not the place to explore it. We could perhaps profit from experimentation. We might try a very modest payment to everyone injured and retain the negligence suit but with certain of its excrescences lopped off. It is more difficult to police the automobile risk than the industrial accident risk. If to a certain extent the driver's concern for his own safety may induce care, this concern may operate with least effect on the "accident-prone" driver who is the greatest menace. And so perhaps we should, as a further incentive, retain the risk of increased recovery for negligence. But if we permit the driver to insure the whole risk, we do not achieve our objective. We might conclude that the negligent driver should in every case be required to pay part of the loss if he wishes to retain his license. In any case, we should reduce the problem to its essential terms which are (a) the prevention of injury and (b) compensation for such harms and in such measure as the common insurance fund can be fairly asked to provide. 